\title{
Implementation Of Disclosure of Bank Confidentiality In The Effort To Eradicate Money Laundering Crime
}

\author{
Mohammad Fadarisman*) and Bambang Tri Bawono**) \\ *) Civil Servant of Indonesia; emailfadarisman26@gmail.com \\ $\left.{ }^{* *}\right)$ Universitas Islam Sultan Agung (UNISSULA) Semarang
}

\begin{abstract}
The purpose of this research is to identify and analyze the implementation of bank secrecy disclosure in an effort to eradicate money laundering in the construction of legal certainty and to know and analyze the obstacles faced in the implementation of bank secrecy disclosure in an effort to eradicate money laundering. ) in the perspective of law enforcement. This study uses a sociological juridical approach, which in this case relates to the role of the State Attorney in recovering state financial losses with descriptive analytical research specifications. The data used are primary and secondary data which will be analyzed qualitatively. The research problem was analyzed using the theory of justice and the theory of expediency. The results of the study conclude that the eradication of money laundering in Indonesia will not be effective against law enforcers, both the police, prosecutors, and judges who investigate, prosecute, and examine cases of money laundering crimes, but the bank secrecy provisions as referred to in the Banking Law. Meanwhile, the obstacles faced by law enforcement officers in conducting investigations and investigations of money laundering practices are: 1) Weak provisions for bank secrecy, 2) Bank Indonesia secrecy with exceptions that are limitative and bureaucratic are considered as obstacles, 3) Law Enforcement Officials cannot know fully accurate financial information stored in the bank belonging to the suspect or defendant,

Keywords: Implementation; Bank Secrecy; Money Laundry.
\end{abstract}

\section{Introduction}

Money Laundering as a second-tier crime (predicate crime) is a crime that accompanies a predicate crime, money laundering is a crime that can hide in the financial and banking system in a country, so that this crime or crime is a concern because there are several things related to money laundering specializing in finance and banking. In line with technological developments and globalization in the economic field, the crime of money laundering through banks as a provider of financial services is an easy target for the mode most chosen by money laundering criminals in Indonesia. , among others, namely the existence of a clearing and remittance system that facilitates the circulation of money, so that the origin of the money can no longer be traced, and the most profitable for perpetrators of money laundering through banking occurs because of the application of strict bank secrecy provisions which are generally upheld by banks. For modern countries, the desire to effectively guarantee the rights of citizens and regulate the orderly state administration has encouraged every country to adopt constitutionalism. It is believed that the best way to this end is through a constitution, so constitutionalism for modern countries is a necessity. The desire to effectively guarantee the rights of citizens and regulate the orderly state administration has 
encouraged every country to adopt constitutionalism. It is believed that the best way to this end is through a constitution, so constitutionalism for modern countries is a necessity. The desire to effectively guarantee the rights of citizens and regulate the orderly state administration has encouraged every country to adopt constitutionalism. It is believed that the best way to this end is through a constitution, so constitutionalism for modern countries is a necessity. ${ }^{1}$

A criminal act is an act that is prohibited by a statutory regulation, where the prohibition is accompanied by the threat of sanctions in the form of certain crimes for anyone who violates the prohibition. The settlement of criminal cases is carried out through the evidentiary process, namely the prosecution process which is carried out directly in an experiment. ${ }^{2}$ In judicial practice, the process always begins with an arrest, detention, then being prosecuted by the public prosecutor, which ends with a judge's decision. ${ }^{3}$

According to Article 1 number 28 of the Banking Law, "Bank secrets are everything related to information regarding depositors and their deposits". ${ }^{4}$ Due to the high commitment held by banks to maintain customer confidentiality, this principle is often used as a shield for perpetrators of money laundering crimes to hide the origin of funds recorded to him and other matters that must be kept secret by the bank according to the norm in the banking world, except in matters stipulated in this Law.

Banking is one of the providers of financial services that saves and distributes money originating from the state as well as from the community from its customers. However, banking institutions have also become the main means of storing assets derived from these crimes. The targets of Money Laundering actors are countries that have minimal provisions in the banking sector, namely countries that still uphold the strict principle of bank secrecy. The lack of regulations in the field of banking and strict bank secrecy in a country can make it possible for money launderers to freely use banking facilities for the purpose of obscuring the proceeds of crime. 5

The rigid and closed nature of the bank secrecy principle is one of the factors that can lead to widespread money laundering practices in a country and is also a factor in the success or failure of preventing and eradicating money laundering crimes. The principle of prudence in managing funds must be used as a way of thinking by bankers. This also means that the precautionary principle must be proactively adopted. The failure of the organizers of banking businesses is mostly due to the lack of prudence on the part of the banking sector in managing public funds. This in turn causes the bank to be in a difficult and dangerous

\footnotetext{
${ }^{1}$ Adhe I smail A, Constitutionalism Concept in Implementation of Indonesian State Administration. Jurnal Daulat Hukum Volume 4 Issue 2, June 2021 ISSN: 2614-560X.

${ }^{2}$ Ardito, YP, Umar Ma'ruf and Aryani Witasari. Implementation of Criminal Action Prosecution Online in Realizing Principle of Fast Prosecution, Simple \& Low Cost, Jurnal Daulat Hukum, Volume 4 Issue 2, June 2021 ISSN: 2614-560X.

${ }^{3}$ Ferry, SW and Arpangi. Settlement Policy of Criminal Actions which Performed by Children through Penal Mediation. Jurnal Daulat Hukum Volume 4 Issue 2, June 2021 ISSN: 2614-560X.

${ }^{4}$ Act No. 10 of 1998 concerning Banking

${ }^{5}$ Interview with Police Commissioner Dwi Edi Purnomo, SH, MH, Head of the Central Java Police Ditresmsus Unit.
} 
position. The Bank's confidential obligations that must be adhered to by the Bank are not solely for the benefit of the customers themselves.

Banks are business entities that collect funds from the public and run their business mainly from public funds and then distribute them back to the community. In addition, the Bank also provides financial services and other payments. ${ }^{6}$ In the world of banking, customers are consumers of banking services. The position of customers in relation to banking services is in two positions that can be alternated according to which side they are on. Viewed from the point of view of the mobilization of funds, customers who deposit their funds with the Bank either as depositors or buyers of securities, then at that time the customer is a creditor of the Bank. Provisions regarding bank secrecy are a very important matter for Depositing Customers and their deposits as well as for the interests of the Bank itself, because if this Depositing Customer does not trust the Bank where he keeps his deposits, of course he will not want to become his customers. Therefore, as a financial institution whose function is to collect funds from the public in the form of savings. ${ }^{7}$

The purpose of this study is to identify and analyze the implementation of bank secrecy in an effort to eradicate money laundering in the construction of legal certainty, to identify and analyze the obstacles faced in implementing bank secrecy in an effort to eradicate money laundering in the perspective of law enforcement.

\section{Research Methods}

The approach method used in this study uses a sociological juridical method which in this case relates to the implementation of bank secrecy disclosure in an effort to eradicate money laundering in the perspective of law enforcement. The specifications in this study are analytical descriptive.

Sources of data used in this study is primary data sources. ${ }^{8}$ Primary data sources are objects that are observed directly in the field and interviewed informants. Primary legal materials consist of: Act No. 8 of 1999 concerning Eradication of the Crime of Money Laundering. Tertiary legal materials consist of dictionaries, encyclopedias.

The data collection method used to obtain data that has a relationship with the object of research is interviews with resource persons and document review, while the data analysis method used is qualitative data analysis in this study including data reduction, data presentation and conclusions/verification.

\section{Results and Discussion}

\subsection{Implementation of Disclosure of Bank Secrets in Efforts to Eradicating the Crime of Money Laundering}

\footnotetext{
6Erna Priliasari, 2008. MediasiPerbankan Sebagai Wujud Perlindungan Terhadap Nasabah Bank, Direktorat Jendral Peraturan Perundang-undangan Departemen Hukum dan Hak Asasi Manusia, Jakarta, p.25.

${ }^{7}$ Muhammad Djumhana, Memerangi Pencucian Uang, Jurnal Hukum Bisnis, Vol.16, November 2000, p. 4.

${ }^{8}$ Soerjono Soekanto, 2010, Pengantar Penelitian Hukum, Universitas Indonesia Press, Jakarta, p. 10.
} 
Bank secrecy itself has a dilemma in the investigation of a crime. Banks as financial service providers have an obligation to protect their customers so that they can become trusted banks in the eyes of the public. However, on the other hand, the bank must not protect the existence of a crime that makes it the locus of crime. To prevent losses for finance companies, order and smooth payments need to be guaranteed, and given that credit agreements require a certain amount of money and many consumers are negligent in making them, all payments need guarantees. ${ }^{9}$

From the side of law enforcement in investigating a crime, they have difficulty in the investigation process to collect evidence related to the existence of a crime. Law enforcers must carry out what is stated in the laws and regulations, but they are in conflict with the Bank Secrecy Provisions, while banks may not simply disclose information about their customers to law enforcement.

Another thing related to the weakness of the bank secrecy regulation itself is that the regulation does not accommodate the court to order the bookkeeping of bank secrecy. Court decisions cannot be used as a reason to disclose bank secret information.

In Article 42 of Act No. 7 of 1992 concerning Banking as amended in Act No. 10 of 1998, states that:

"Police, prosecutors and judges who wish to obtain bank secret information must obtain permission from the Governor of Bank Indonesia, through the Chief of Police, Attorney General, and Chief Justice of the Supreme Court of the Republic of Indonesia, respectively."

If the article is reviewed, there are significant weaknesses. From a constitutional point of view, there is an oddity why a judicial institution headed by the Supreme Court, a State High Institution, must seek permission from the leadership of Bank Indonesia to obtain bank secret information. In fact, in this case the position of the Supreme Court is equal to the President and is higher than the leadership of Bank Indonesia.

From the explanation above, bank secrecy is a very significant and fundamental obstacle in investigating money laundering crimes that are closely related to banks. There is an opinion or perception that the provisions on bank secrecy in Indonesia with exceptions that are limited and bureaucratic can be considered as obstacles to the law enforcement process in Indonesia. In this regard, the Financial and Development Supervisory Agency (BPKP) is of the opinion that:

"Bank secrecy is an obstacle in eradicating a crime. Some even think that the provisions on bank secrecy can be used as a "shield" for hiding for criminals."10

Law enforcement officials have a close relationship with industry banking in accordance with the duties and authorities of each party. Because banks can be used as targets for criminal acts or the locus of a crime, law enforcement officers should support each other and work together in an effort to uncover criminal acts

\footnotetext{
${ }^{9}$ Angga K and Aryani Witasari. Law Enforcement on Fiducian Security Objects Due to Withdrawal of Fiducia Security Objects.Law Development Journal ISSN : 2747-2604 Volume 3 Issue 1, March 2021, $(38-43)$.

${ }^{10}$ Ibid, p. 9
} 
committed by a person or entity. As a locus that can be used by perpetrators of criminal acts, banks can be used as a place to store, hide or obscure the origin of the proceeds of a crime. To carry out a legal action such as blocking and or confiscation of funds held by a bank, law enforcement officers often require information from the bank.

According to Article 42 of Act No. 7 of 1992 concerning Banking as amended in Act No. 10 of 1998, for the purposes of justice in criminal cases, the police, prosecutors or judges may request information about the financial condition of a suspect or defendant who has deposits in a bank. The request for information shall be submitted for written permission by the Head of the Indonesian National Police, the Attorney General, or the Chief Justice of the Supreme Court to the Management of Bank Indonesia.

However, in the field implementation, this provision has not been able to run effectively because the process required is relatively long to obtain the said permit. On the other hand, technological advances and bank services that continue to develop make suspects or defendants, taxpayers, and debtors (debt bearers) in a matter of minutes able to immediately transfer their funds to the accounts of other parties such as friends or relatives. or obtain the necessary evidence of a criminal offence. To overcome this situation, investigators sometimes take shortcuts to obtain bank secret information, namely by asking the customer who is a suspect to authorize the investigator to ask for information from the bank.

Another way that can be done is to ask the customer to authorize the bank to provide information about the customer's financial condition to other parties. If we look at the situation, actually the actions of the investigators are very dangerous for the investigation and settlement of cases related to bank secrecy, because the actions of the investigators have no regulation. This will have consequences for investigators if the procedure for permitting to open bank secrecy is not fulfilled, then it is very likely that the evidence used by the investigator or public prosecutor will be rejected by the court, especially if the defendant has a problem with it.

It is necessary to remember that the condition of the suspect or defendant in granting permission to disclose his financial information which is classified as bank secret to law enforcement officers, is in a state of threat or in a safe condition. In addition, often the officer who gives permission to open the account of a person suspected of having committed a crime also conducts examinations of other accounts. Like the accounts of relatives or other accounts that actually have no relationship at all ${ }^{11}$. According to the police, this action is needed to track the flow of funds from the suspect, so that they can obtain sufficient and optimal evidence to prove the existence of a money laundering crime and ultimately impose criminal sanctions on the perpetrators. In fact, this police action is not in accordance with the provisions as stated in Article 42 of Act No. 7 of 1992 concerning Banking as amended in Act No. 10 of 1998. To overcome this problem, investigators often apply for a permit to examine the suspect's financial condition to the leadership of Bank Indonesia with the formula "to examine the circumstances and documents

${ }^{11}$ Yunus Huseindan Roberts K, Tipologi dan Perkembangan Tindak Pidana Pencucian Uang, Depok: Rajawali Pers, 2018, p.11. 
related to the account in the name of the suspect". In this way, the investigator also conducts an examination on other accounts that are related to the suspect's account.

In terms of blocking and confiscation of funds in the suspect's bank account, so far the implementers in the field have had the wrong perception in applying coercive measures. As it is known that blocking is not regulated in the Criminal Procedure Code (KUHAP), but is regulated in other laws and regulations such as Act No. 31 of 1999 concerning the Eradication of Corruption Crimes as amended by Act No. 20 of 2001, Act No. 15 of 2003 concerning the Crime of Terrorism and Act No. 15 of 2002 concerning the Crime of Money Laundering as amended into Act No. 25 of 2003. Until now the laws and regulations governing the blocking and confiscation of bank accounts have not been adequate. Furthermore, this blocking issue is briefly regulated in Act No. 31 of 1999 concerning the Eradication of Corruption Crimes as amended by Act No. 20 of $2001^{12}$.

\subsection{Obstacles Faced in the Implementation of Opening Bank Secrets in Efforts to Eradicating the Crime of Money Laundering}

Obstacles and obstacles for law enforcement officers in conducting investigations and investigations of money laundering practices related to the Bank Secrecy Provisions regulated in Act No. 7 of 1992 concerning Banking as amended into Act No. 10 of 1998, are as follows:

\subsubsection{Weak Bank Secrecy Provisions.}

Current bank secrecy provisions are still not perfect, including in relation to efforts to support the interests of the civil justice process, criminal justice, state administrative courts, religious courts and military courts.

In handling cases involving bank secrecy, investigators, public prosecutors or judges often request expert information from Bank Indonesia as the institution responsible for bank development and supervision. In providing information by the expert witness, Bank Indonesia officials often made interpretations which sometimes expanded the contents of the bank secrecy provisions. ${ }^{13}$

Another thing that has not been adequately regulated in the context of bank secrecy provisions is regarding the confiscation or blocking of accounts in criminal cases. So far, the regulation of confiscation and blocking of customer accounts has not been regulated in the Criminal Procedure Code (KUHAP), but is only based on a Bank Indonesia Circular which forwards letters or instructions from the Commander of the Police Force and the Attorney General to his staff.

In the Circular it is stated that the blocking of accounts is carried out based on a Confiscation Order. One of the dominant reasons for the emergence of bank secrecy cases is because the regulations are still incomplete. As a result, it does not provide legal certainty for the parties involved. This uncertainty can lead to

\footnotetext{
12 Ibid, p. 11

13Yunus Husein, 2003. Rahasia Bank: Privasi Versus Kepentingan Umum. Jakarta, Pasca Sarjana Fakultas Hukum Universitas Indonesia, p.261
} 
inefficiency, due to the large number of questions and reporting cases involving bank secrecy.

The issue of bank secrecy which is also related to the judiciary is regarding the provision of bank secrecy information in court hearings open to the public. In general, the examination of cases is open to the public. In the examination of criminal cases, the trial can be held closed to the public, only for cases concerning decency or where the defendant is a child. Court transparency is required, among others, to:

a. Maintain public confidence in an impartial tribunal.

b. In the framework of the rule of law. Transparency can prevent abuse of power and wrongdoing 14

Thus, if the litigants, defendants or their lawyers disclose information that is bank secret, the information can be known by the public because the court session is open to the public. Examinations in criminal courts cannot be carried out in private, even though the information submitted is bank secret, except for cases of immorality and cases where the defendant is a child.

\subsubsection{Bank Indonesia secrecy with exceptions that are limited and bureaucratic is} considered an obstacle to the law enforcement process in Indonesia

In practice, to overcome a very dilemmatic situation regarding bank secrecy provisions, the police often ask the suspect or defendant to give power of attorney to the police in order to penetrate the bank secrecy provisions and obtain the required information from the bank concerned. This is intended to take the fastest step and race against time considering the very tight bureaucracy to apply for a permit to open bank secrets from the leadership of Bank Indonesia, that the time for granting permission to open bank secrets is given by the Governor Bank Indonesia is 14 (fourteen) days, while very advanced technology can benefit the suspect or the defendant himself to move his account to another place in just a matter of minutes. This can result in the loss of information or evidence needed by the police to process the crime. The police is a subsystem in the criminal justice system that is sufficient to determine the success and work of the entire system in providing services to the public. ${ }^{15}$

\subsubsection{Law Enforcement Officials cannot know accurately about financial information} stored in banks belonging to suspects or defendants who commit money laundering crimes.

In this case, the bank will be very careful in disclosing any information about the financial condition of its clients, considering that bank secrecy has become a guideline in the implementation of banking and is the key to success in becoming a trusted bank in the eyes of the public. The Bank will not immediately provide information to all parties who request information about the financial condition of their customers. In fact, the main difficulty in the investigation is that

\footnotetext{
14 Ibid, p. 330

${ }^{15}$ Nurfita A T, Sri Endah Wahyuningsih dan Arpangi. The Police Role in Investigating the Crime of Child Murder as a Result of Infidelity Relationships.Law Development Journal ISSN : 2747-2604 Volume 3 Issue 1, March 2021, (86 - 92).
} 
the police cannot find out financial information from the bank regarding the alleged criminal act of money laundering before the perpetrator in question is designated a suspect.

\subsubsection{It is impossible for the police to obtain information on the financial condition of} a person who has not been named a suspect/accused.

This fourth obstacle is very difficult in terms of initial investigation of an alleged criminal act, specifically the crime of money laundering. In the Criminal Procedure Code (KUHAP) it is stated that an investigation is a series of investigators' actions to seek and find an event that is suspected of being a criminal act in order to determine whether or not an investigation can be carried out according to the method regulated by this law. This means that the police must look for other evidence if they are to determine that someone has committed a money laundering crime even though the crime is closely related to the bank, where the main evidence lies with the bank.

In this regard, in today's electronic era, the act of moving money from one account to another only takes a few seconds, so law enforcement officers find it difficult to track and confiscate the proceeds of criminal acts deposited in banks. This obstacle has not been fully accommodated in the provisions regarding bank secrecy. ${ }^{16}$

\section{Closing}

The conclusion in this study is that the eradication of money laundering in Indonesia will not be effective against law enforcers, both the police, prosecutors, and judges who conduct investigations, prosecute, and examine cases of money laundering crimes, the provisions of bank secrecy will still apply as referred to the Banking Law. Obstacles faced by law enforcement officers in conducting investigations and investigating the existence of money laundering practices are related to the Bank Secrecy Provisions regulated in Act No. 7 of 1992 concerning Banking as amended into Act No. 10 of 1998, namely: 1) Weak provisions for bank secrecy, 2) Bank Indonesia secrecy with exceptions that are limited and bureaucratic in nature are considered as obstacles to the law enforcement process in Indonesia,

Suggestions in this study are the suggestions in this study, namely the need to amend Act No. 7 of 1992 concerning Banking as amended into Act No. 10 of 1998 concerning Banking and closer cooperation is needed between law enforcers and the Bank so that all evidence on the Bank's side can be easily accessed by law enforcement officers.

\section{References}

\section{Journal}

16 Interview with Aiptu Catur Feski P, SH, Assistant Investigator of the Central Java Police Ditreskrimsus. 
[1] Adhe I smail A,Constitutionalism Concept in Implementation of Indonesian State Administration. Jurnal Daulat Hukum Volume 4 Issue 2, June 2021 ISSN: 2614-560X.

[2] Angga K dan Aryani Witasari. Law Enforcement on Fiducian Security Objects Due to Withdrawal of Fiducia Security Objects. Law Development Journal ISSN : 2747-2604 Volume 3 Issue 1, March 2021, (38 - 43).

[3] Ardito, Y P, Umar Ma'ruf and Aryani Witasari. Implementation of Criminal Action Prosecution Online in Realizing Principle of Fast Prosecution, Simple \& Low Cost, Jurnal Daulat Hukum, Volume 4 Issue 2, June 2021 ISSN: 2614$560 \mathrm{X}$.

[4] Feri, S W, and Arpangi. Settlement Policy of Criminal Actions which Performed by Children through Penal Mediation. Jurnal Daulat Hukum Volume 4 Issue 2, June 2021 ISSN: 2614-560X.

[5] Muhammad Djumhana, Memerangi Pencucian Uang, Jurnal Hukum Bisnis, Vol.16, November 2000.

[6] Nurfita A T, Sri Endah Wahyuningsih and Arpangi. The Police Role in Investigating the Crime of Child Murder as a Result of Infidelity Relationships.Law Development Journal ISSN : 2747-2604 Volume 3 Issue 1, March 2021, (86 - 92).

\section{Book}

[1] Erna Priliasari, 2008. Mediasi Perbankan Sebagai Wujud Perlindungan Terhadap Nasabah Bank, Direktorat Jendral Peraturan Perundang-undangan Departemen Hukum dan Hak Asasi Manusia, Jakarta.

[2] Soerjono Soekanto, 2010, Pengantar Penelitian Hukum, Universitas Indonesia Press, Jakarta.

[3] Yunus Husein dan Roberts K, 2018, Tipologi dan Perkembangan Tindak Pidana Pencucian Uang, Depok: Rajawali Pers. 